\title{
STRATEGI PEMBELAJARAN GURU KEAGAMAAN PADA MASA PANDEMI COVID-19 DI MTs MUSLIMAT NU PALANGKA RAYA
}

\author{
${ }^{1}$ Jakirah, ${ }^{2}$ Jasiah, ${ }^{3}$ Marsiah \\ Institut Agama Islam Negeri Palangka Raya \\ jakirahja7@gmail.com ${ }^{1}$ jasiah@iain_palangkaraya.ac.id ${ }^{2}{ }^{\text {marsiah@iain-palangkaraya.ac.id }}{ }^{3}$
}

\begin{abstract}
This study aims to examine the learning strategies used by the religious teachers of MTs Muslimat NU Palangka Raya during the Covid-19 pandemic. The research method used is a qualitative descriptive method The results of this study indicate that religious teachers at MTs Muslimat NU Palangka Raya use an online learning strategy by making teaching videos and created a WhatsApp group to share videos, attendance and assignments with students, as well as questions and answers regarding learning material that was unclear for students. Religious teachers in MTs Muslimat NU Palangkaraya run an online learning strategy with a supporting factor that all teachers and students have Hp, internet networks in schools, and all the teachers and students have app whatsapp faced.The obstacle faced is that the teacher has difficulty checking student assignments because there are several students sending assignments at once not according to the assignment collection schedule.
\end{abstract}

Keywords: Covid-19, Learning, Pandemic, Strategies.

\begin{abstract}
Abstrak
Penelitian ini bertujuan untuk mengkaji strategi pembelajaran yang digunakan oleh guru keagamaan di MTs Muslimat NU Palangka Raya selama masa pandemi covid-19. Metode penelitian yang digunakan adalah metode deskriptif kualitatif. Hasil penelitian ini menunjukkan bahwa guru keagamaan di MTs Muslimat NU Palangka Raya menggunakan strategi pembelajaran daring dengan membuat video mengajar dan membuat group whatsapp untu berbagi video, absensi dan tugas kepada siswa, serta tanya jawab terkait materi pembelajaran yang kurang jelas. Guru keagamaan di MTs Muslimat NU Palangka Raya menerapkan strategi pembelajaran daring dengan faktor pendukung yaitu semua guru dan siswa memiliki Hp, ada internet di sekolah, dan semua guru dan siswa memiliki aplikasi whatsapp. Kendala yang dihadapi adalah guru kesulitan untuk mengecek tugas siswa karena ada beberapa siswa yang mengirimkan tugas secara bersamaan tidak sesuai dengan jadwal pengumpulan tugas.
\end{abstract}

Kata Kunci: Covid-19, Pandemi, Pembelajaran, Strategi. 


\section{PENDAHULUAN}

Virus corona baru yang dikenal sebagai COVID-19 merebak di China pada akhir Desember 2019 dan menyebar di beberapa negara yang dinyatakan oleh Organisasi Kesehatan Dunia sebagai pandemi global. Coronavirus disease 2019 (covid19) merupakan jenis penyakit baru yang belum pernah ditemukan pada manusia sebelumnya. Tanda dan gejala umum infeksi COVID-19 termasuk gejala gangguan pernapasan akut, seperti demam, batuk, dan sesak napas. Pada 2 Maret 2020, Indonesia telah melaporkan 2 kasus terkonfirmasi COVID-19 hingga 16 Maret 2020 terdapat 10 orang yang dinyatakan positif corona. Wabah virus corona secara global telah mempengaruhi semua bidang termasuk pendidikan (Dewi, 2020).

Keberhasilan pendidikan sangat bergantung pada penguasaan guru terhadap strategi pembelajaran. Strategi pembelajaran adalah rangkaian kegiatan yang meliputi penggunaan metode dan penggunaan berbagai sumber atau kekuatan dalam pembelajaran yang dirancang untuk mencapai tujuan tertentu, yaitu tujuan pembelajaran (Majid, 2013).

Strategi tidak hanya sekedar langkah atau tindakan, tetapi juga strategi yang telah dipertimbangkan dengan cermat pro dan kontra, efek positif dan negatifnya. Dapat disimpulkan bahwa ketika guru merencanakan strategi pembelajaran dihasilkan melalui proses berpikir yang cermat, cermat dan mendalam, agar tidak menurunkan kualitas pembelajaran dan tujuan pendidikan (Nata, 2014).

Menteri Pendidikan dan Kebudayaan Republik Indonesia, Nadiem Anwar Makariem mengeluarkan Surat Edaran Nomor 4 Tahun 2020 tentang pelaksanaan kebijakan pendidikan selama masa darurat penyebaran COVID-19 bahwa pemerintah menerapkan kebijakan proses belajar dilaksanakan di rumah melalui pembelajaran jarak jauh, hal ini dilakukan untuk memutus mata rantai penyebaran virus covid-19 (Menteri Pendidikan, 2020).

Menurut Suhendro (2020) strategi pembelajaran daring merupakan bentuk lain yang diberikan kepada siswa sebagai bagian dari implementasi strategi pembelajaran di masa COVID-19. Proses pembelajaran secara daring ini diharapkan dapat menjadi solusi agar siswa tidak terpapar virus COVID-19. Penelitian sebelumnya telah menunjukkan bahwa strategi pembelajaran daring adalah strategi pembelajaran yang digunakan pada saat pandemi covid-19. Sebagian contoh, hasil penelitian Nikmah (2020) menunjukkan bahwa strategi pembelajaran daring merupakan strategi yang paling cocok untuk situasi 
pandemi dan diterapkan di Jurusan Akutansi Poilban. Selain itu, Mashuri (2020) menunjukkan dalam hasil penelitiannya bahwa strategi pembelajaran daring yang digunakan guru SMP Negeri 1 Bahorok Kabupaten Langkat adalah dengan mengunjungi rumah siswa dan mengajari siswa dan orang tua siswa cara menggunakan internet serta media yang akan digunakan selama daring. Dapat disimpulkan bahwa pembelajaran daring merupakan bagian dari strategi pembelajaran yang diterapkan selama pandemi COVID-19.

Menjalankan strategi pembelajaran yang baru ditengah pandemi nyatanya ada hambatan yang dialami oleh guru. Keputusan pemerintah untuk mengubah proses kegiatan belajar mengajar melalui penggunaan sistem daring telah menyebabkan beberapa masalah bagi siswa dan guru. Misalnya, akses informasi yang dibatasi oleh sinyal, yang terkadang menyebabkan siswa ketinggalan informasi akibat sinyal yang kurang memadai. Terlebih lagi, guru memberikan banyak pekerjaan rumah kepada siswa, membuat ruang penyimpanan perangkat lebih terbatas (Siahaan, 2020).

Pendapat di atas menunjukkan bahwa meskipun strategi pembelajaran daring merupakan alternatif yang tepat untuk digunakan dalam proses pembelajaran pada masa pandemi covid-19, pembelajaran daring tidak lepas dari permasalahan yang menjadi kendala dalam penerapannya, sehingga menerapkan strategi pembelajaran daring merupakan suatu tantangan sendiri untuk lembaga pendidikan.

Menurut hasil wawancara dengan wakamad kurikulum di ruang guru MTs Muslimat NU Palangka Raya pada 16 Juli 2020, ibu M mengatakan bahwa pada masa pandemi COVID-19 dan sejak dikeluarkannya larangan melaksanakan pembelajaran secara langsung atau tatap muka, MTs Muslimat NU Palangka Raya ikuti anjuran pemerintah dan lakukan proses belajar mengajar di rumah. Proses belajar yang berubah juga mempengaruhi strategi yang digunakan dalam mengajar. Sebelum pandemi COVID19 mata pelajaran Pendidikan Agama Islam memiliki strategi tersendiri seperti menggunakan metode ceramah, diskusi, maupun metode penugasan lainnya, namun akibat pandemi covid-19 maka guru keagamaan mengubah strategi yang digunakan sebelumnya dengan strategi baru yang sesuai dengan keadaan pandemi COVID-19.

Strategi yang digunakan sebelum pandemi covid-19 sulit digunakan oleh institusi pendidikan di masa pandemi covid-19 karena mengharuskan pertemuan tatap muka langsung antara guru dan siswa. Maka dari itu peneliti ingin meneliti lebih jauh strategi 
pembelajaran guru keagamaan pada masa pandemi covid-19 di MTs Muslimat NU Palangka Raya.

\section{METODE PENELITIAN}

Metode penelitian yang digunakan dalam penelitian ini adalah metode deskriptif kualitaitif. Peneliti mendeskripsikan strategi pembelajaran guru keagamaan pada masa pandemi COVID-19 di MTs Muslimat NU Palangka Raya. Teknik pengumpulan data yang digunakan dengan metode wawancara dan dokumentasi. Teknik analisis data dengan melakukan reduksi data, penyajian data, dan penarikan kesimpulan. Waktu untuk melakukan penelitian yaitu pada saat pandemi covid-19 mulai bulan Agustus 2020 hingga Oktober 2020. Penelitian ini dilaksanakan di MTs Muslimat NU Palangka Raya yang beralamat di Jl. Pilau No. 41 Kelurahan Pahandut, Kecamatan Pahandut, Kota Palangka Raya, Provinsi Kalimantan Tengah.

\section{HASIL DAN PEMBAHASAN}

\section{A. Strategi Pembelajaran Guru Keagamaaan Pada Masa Pandemi Covid-19 di MTs}

\section{Muslimat NU Palangka Raya}

Strategi dalam konteks pendidikan adalah merencanakan apa yang akan kita lakukan, atau serangkaian tujuan yang akan kita capai, dan tujuan tersebut akan bermuara pada terwujudnya tujuan pendidikan. Pendidik menggunakan strategi pembelajaran untuk mencapai tujuan pembelajaran secara efektif dan efisien (Nikmah, 2020).

Berdasarkan Peraturan Pemerintah Nomor 4 Tahun 2020, kebijakan penerapan kebijakan pendidikan dalam situasi darurat penyebaran penyakit virus Corona, proses pembelajaran dilakukan secara online di rumah. Penerapan kebijakan pembelajaran online oleh pemerintah akan mempengaruhi strategi mengajar guru.

Guru keagamaan di MTs Muslimat NU Palangka Raya mengatakan bahwa strategi pembelajaran yang digunakan pasca pandemi berbeda dengan sebelum pandemi, sebelum pandemi datang menggunakan metode ceramah, diskusi dan penugasan lainnya yang dilaksanakan dengan tatap muka di sekolah. 
Menurut hasil wawancara dengan para guru keagamaan MTs Muslimat NU Palangka Raya, selama masa pandemi COVId-19, para guru keagamaan menggunakan strategi pembelajaran daring untuk melakukan kegiatan pembelajaran di masa pandemi COVID-19 dengan membuat video mengajar dan membuat group whatsapp.

Guru keagamaan di MTs Muslimat NU Palangka Raya mengatakan strategi pembelajaran daring menjadi strategi yang dipilih sekolah karena Palangka Raya masih berada di zona merah penyebaran virus COVID-19, sehingga guru dan siswa tidak boleh bertemu di sekolah untuk mengurangi penyebaran virus COVID-19.

Secara teori, strategi pembelajaran daring merupakan cara alternatif yang diberikan kepada siswa sebagai bagian dari implementasi strategi pembelajaran di masa COVID-19. Pembelajaran dalam jaringan menggunakan media handphone, laptop melalui beberapa aplikasi pembelajaran online, dan web (Suhendro, 2020).

Strategi pembelajaran daring yang digunakan guru keagamaan di MTs Muslimat NU Palangka Raya yaitu membuat video mengajar yang di dalamnya terdapat guru yang sedang menjelaskan materi. Guru membuat video agar materi pelajaran tetap tersampaikan kepada siswa. Berdasarkan hal tersebut, menunjukkan bahwa guru tidak dapat melakukannya tanpa penggunaan media ketika menerapkan strategi pembelajaran.

Pendapat di atas didukung oleh teori Syafi'i, dkk yang mengemukakan bahwa media pembelajaran merupakan sesuatu yang strategis dalam proses pembelajaran karena media merupakan penghubung informasi yang akan diberikan guru kepada siswa (Syafi'i, Sa'diyah, Wakhidah, \& Umah, 2020).

Video merupakan media pembelajaran yang bisa dipakai untuk pembelajaran daring. Media pembelajaran berupa video memudahkan anak didik karena dapat diulang-ulang selama proses pembelajaran, hal tersebut memudahkan anak didik dalam memahami isi video (Fauziyah, 2020).

Pendapat di atas menunjukkan bahwa media merupakan bagian strategi sebagai penghubung guru dengan siswa. Media yang digunakan guru keagamaan di MTs Muslimat NU Palangka Raya sudah tepat untuk digunakan dalam pembelajaran daring karena video membantu guru menyampaikan materi pembelajaran dari jarak jauh dan memudahkan siswa dalam memahami isi materi karena video dapat diputar berulang kali selama proses pembelajaran. 
Proses pembelajaran daring juga terkait erat dengan penggunaan aplikasi sebagai sarana yang digunakan guru untuk menyampaikan materi kepada siswa. Pembelajaran daring pada dasarnya adalah pembelajaran yang dilakukan secara praktis melalui aplikasi virtual yang tersedia (Syarifudin, 2020).

Secara teori, pembelajaran daring merupakan penggunaan jaringan internet pada proses pembelajaran. Siswa bisa berinteraksi dengan guru melalui berbagai aplikasi seperti google classroom, telepon atau live chat, zoom maupun melalui group whatsapp (Dewi, 2020).

Pembelajaran daring sangat dikenal di masyarakat dan di kalangan akademisi sebagai pembelajaran online (online learning). Pembelajaran daring merupakan pembelajaran yang berlangsung pada jaringan dimana pengajar dan anak didik tidak secara langsung tatap muka (Pohan, 2020).

Pembelajaran daring dilakukan dengan menggunakan komputer pribadi (PC) atau semua perangkat yang terkoneksi dengan internet. Guru dapat menggunakan grup di media sosial untuk belajar, seperti whatsapp (WA), telegram, instagram, aplikasi zoom atau cara lainnya. Dapat disimpulkan bahwa guru dan siswa menggunakan aplikasi yang terkoneksi internet untuk berinteraksi dalam proses pembelajaran daring (Hartati, Thahir, \& Fauzan, 2020).

Pembelajaran daring adalah hal baru bagi guru dan siswa. Guru dan siswa harus pandai menggunakan perangkat elektronik khususnya internet, sehingga dalam memilih aplikasi yang akan digunakan harus didasarkan kemampuan guru dan siswa agar interaksi dalam proses pembelajaran tetap berjalan dengan baik (Rigianti, 2020).

Hasil wawancara dengan guru keagamaan MTs Muslimat NU Palangka Raya menunjukkan bahwa guru membuat group whatsapp untuk berinteraksi dengan siswa, membagikan absensi, video dan tugas dengan siswa, serta bertanya kepada siswa terkait materi yang belum jelas. Hal ini menunjukkan bahwa selama proses pembelajaran daring guru dan siswa di MTs Muslimat NU Palangka Raya berinteraksi menggunakan aplikasi whatsapp.

Sesuai dengan teori, aplikasi whatsapp mudah digunakan untuk mengirim pesan, group chat, foto, video, dan dokumen dengan fungsi tersebut guru dapat berbagi topik pembelajaran dengan siswa (Hutami \& Nugraheni, 2020). 
Kelebihan dari aplikasi whatsapp adalah dapat berinteraksi dengan maksimal 250 anggota grup, sehingga ketika ada pembelajaran daring, semua siswa dapat masuk sesuai materi pembelajaran atau kelasnya, tanpa batasan tempat. Pesan yang terkirim juga tidak dibatasi waktunya sehingga memudahkan pembelajaran daring saat guru memberikan materi pembelajaran. Pesan yang masuk akan otomatis tersimpan sehingga jika ada siswa yang tertinggal dapat melihat kembali pesan-pesan yang telah dikirim oleh guru. Aplikasi ini cocok digunakan dalam pembelajaran daring (Fauziyah, 2020).

Pendapat di atas menunjukkan bahwa penerapan strategi pembelajaran daring tidak terlepas dari penggunaan aplikasi. Pelaksanaan pembelajaran daring membutuhkan aplikasi sebagai sarana untuk menghubungkan guru dengan siswa, karena mereka tidak dapat bertemu secara langsung. Aplikasi whatsapp merupakan aplikasi yang tepat digunakan dalam proses pembelajaran daring karena memberikan fungsi yang memudahkan guru dan siswa untuk berkomunikasi.

Berdasarkan hasil pembahasan di atas, dapat disimpulkan bahwa strategi pembelajaran daring yang digunakan guru keagamaan pada masa pandemi covid-19 di MTs Muslimat NU Palangka Raya yaitu guru membuat video mengajar kemudian dibagikan kepada siswa melalui group whatsapp, dan guru juga membuat group whatsapp sebagai tempat membagikan absensi siswa, tugas kepada siswa, tanya jawab dengan siswa tentang materi yang belum jelas.

\section{B. Faktor Pendukung Strategi Pembelajaran Guru Keagamaan Pada Masa Pandemi Covid-19 di MTs Muslimat NU Palangka Raya}

Sistem pembelajaran online akan berjalan dengan lancar, tentunya didukung oleh semua pihak. Dukungan dapat diperoleh dari internal sekolah itu sendiri, yaitu kualitas sarana dan prasarana pendukung, serta keterampilan guru dan siswa dalam menangani aplikasi.

Dalam proses pembelajaran daring, guru keagamaan MTs Muslimat NU Palangka Raya menyiapkan alat yang efektif dan efektif untuk meredakan ketidaknyamanan siswa dan orang tua. Meski melalui aplikasi, hubungan guru dan murid juga menjadi masih fokus kegiatan pembelajaran. 
Hasil wawancara dengan guru keagamaan di MTs Muslimat NU Palangka Raya menyatakan bahwa ada beberapa faktor pendukung guru dalam menjalankan strategi pembelajaran daring di MTs Muslimat NU Palangka Raya yaitu semua guru dan siswa memiliki handphone. Guru keagamaan di MTs Muslimat NU Palangka Raya mengatakan bahwa handphone menjadi faktor yang mendukung strategi pembelajaran daring, karena handphone sarana untuk belajar, tanpa handphone proses pembelajaran daring tidak terlaksana.

Salah satu aspek penting keberhasilan pelaksanaan pembelajaran daring adalah sarana. Pembelajaran daring adalah pembelajaran yang menggunakan internet, sehingga hal-hal yang berkaitan dengan sarana penunjang pembelajaran daring merupakan faktor penentu keberhasilan proses pembelajaran daring (Rahayu \& Haq, 2020).

Hp, laptop atau komputer merupakan sarana yang sangat penting untuk kelancaran proses pembelajaran daring, yang akan memudahkan guru dalam memberikan materi pelajaran secara daring. Dari teori tersebut menunjukkan bahwa Hp merupakan salah satu sarana yang mendukung untuk proses pembelajaran daring. Jika tidak ada Hp, sulit bagi guru untuk mengirimkan materi kepada siswa (Purwanto et al., 2020).

Hal ini menunjukkan bahwa adanya handphone yang dimiliki guru dan murid di MTs Muslimat NU Palangka Raya membantu proses pembelajaran daring di sekolah karena handphone sebagai sarana yang digunakan guru menyampaikan materi secara online kepada siswa.

Pembelajaran daring merupakan pembelajaran yang dilakukan dalam jaringan melalui internet dan alat pendukung seperti handphone dan komputer. Hal ini menunjukkan bahwa sarana yang digunakan dalam proses pembelajaran daring tidak hanya Hp tetapi didukung dengan jaringan internet karena untuk menyampaikan materi secara daring harus terhubung dengan jaringan internet (Putria, Maula, \& Uswatun, 2020).

Hasil wawancara dengan guru keagamaan di MTs Muslimat NU Palangka Raya bahwa sekolah menyediakan jaringan internet atau wifi bagi guru untuk mengajar selama proses pembelajaran daring. Tersedianya jaringan internet atau wifi yang disediakan sekolah menjadi faktor yang mendukung guru keagamaan di MTs 
Muslimat NU Palangka Raya untuk menerapkan strategi pembelajaran daring di sekolah.

Penerapan pembelajaran daring memanfaatkan teknologi yang tidak terbatas, sehingga pelaksanaan pembelajaran mengalami perubahan. Perubahan tersebut membutuhkan teknologi yang berperan penting dalam bidang pendidikan pada masa pandemi covid-19, guru dan siswa diharapkan mampu menggunakan teknologi (Rahayu \& Haq, 2020).

Pendapat di atas menunjukkan bahwa pembelajaran daring memaksa guru untuk mau tidak mau menggunakan aplikasi untuk proses belajar mengajar sehingga pemilihan aplikasi yang tepat dan mudah digunakan akan membantu keberhasilan proses pembelajaran daring.

Menurut hasil wawancara dengan guru keagamaan di MTs Muslimat NU Palangka Raya mengatakan bahwa faktor yang mendukung guru keagamaan dalam mengajar selama pandemi covid-19 yaitu semua guru dan siswa memiliki aplikasi whatsapp dan adanya aplikasi whatsapp digunakan guru membagikan video dan tugas kepada siswa dan dapat diakses semua pihak.

Sesuai dengan teori, aplikasi whatsapp banyak digunakan di masyarakat, pelajar dan mahasiswa yang dapat mengirimkan informasi multimedia seperti foto, video, dan audio melalui pesan teks sederhana (Fauziyah, 2020).

Proses pembelajaran daring tidak hanya membutuhkan alat pendukung seperti internet, smartphone atau komputer, tapi juga membutuhkan media pendukung. Aplikasi whatsapp merupakan salah satu media yang dapat digunakan dalam proses pembelajaran daring.

Sebelum adanya perintah untuk melakukan pembelajaran secara daring guru, siswa dan orangtua menggunakan whatsapp untuk berkomunikasi. Aplikasi whatsapp digunakan untuk mengetahui informasi kegiatan sekolah atau pertanyaan kemajuan dan aktivitas siswa di sekolah. Hal ini menunjukkan bahwa aplikasi whatsapp merupakan aplikasi yang dapat mendukung proses pembelajaran daring baik fungsinya maupun dari jumlah banyaknya guru, siswa dan orang tua siswa yang menggunakan aplikasi whatsapp ini (Bhagaskara, Afifah, \& Putra, 2021).

Dukungan dalam proses pembelajaran daring juga berasal dari pemilihan aplikasi yang cocok digunakan guru dalam proses pembelajaran daring. Aplikasi 
whatsapp yang dipilih oleh guru keagamaan di MTs Muslimat NU Palangka Raya cocok untuk proses pembelajaran daring, karena selain menggunakan aplikasi whatsapp sederhana dapat diakses oleh semua pihak, guru dan siswa.

\section{Kendala yang dihadapi Guru Keagamaan dalam Menjalankan Strategi Pembelajaran Pada Masa Pandemi Covid-19 di MTs Muslimat NU Palangka Raya}

Perubahan yang cepat dan tiba-tiba yang terjadi akibat penyebaran COVID-19 memaksa semua orang untuk memahami teknologi. Dampak COVID-19 di bidang pendidikan memberikan dampak yang sangat signifikan, terutama bagi guru yang berperan penting dalam pembelajaran daring (Rahayu, Amalia, \& Maula, 2020).

Setiap proses dalam mencapai tujuan pembelajaran pasti ada kendala yang dihadapi guru terlebih lagi ketika pandemi datang. Seperti yang dijelaskan sebelumnya bahwa adanya dampak covid-19 sangat dirasakan pada dunia pendidikan terutama untuk guru. Menurut hasil wawancara dengan guru keagamaan di MTs Muslimat NU Palangka Raya terdapat kendala yang dihadapi guru keagamaan dalam menjalankan strategi pembelajaran daring pada masa pandemi covid-19 yaitu siswa terlambat mengumpulkan tugasnya kepada guru, selain itu beberapa siswa menumpuk tugas dan melakukan pengiriman tugas sekaligus kepada guru tidak sesuai dengan jadwal pengumpulan tugas yang sudah ditentukan, alasan siswa terlambat mengumpulkan tugasnya karena mereka bangun terlambat.

Pandangan ini sejalan dengan teori Rozi bahwa salah satu faktor yang mempengaruhi pembelajaran di masa pandemi adalah menurunnya tanggung jawab siswa. Faktor-faktor yang mempengaruhi proses belajar mengajar di rumah dapat berasal dari siswa itu sendiri. Dalam beberapa kasus, selama pandemi COVID-19, banyak siswa yang tidak masuk kelas karena bangun kesiangan setelah bermain game atau menonton film hingga larut malam (Rozi, 2020).

Pembelajaran di masa pandemi COVID-19 membuat guru dan siswa tidak bisa bertemu secara langsung karena aturan pemerintah untuk social distancing, yang mengakibatkan siswa harus belajar di rumah, tapi banyak siswa yang tidak bisa mengatur jam belajar selama di rumah, sehingga hal itu menjadikan siswa terlambat dalam mengumpulkan tugas kepada guru. 


\section{KESIMPULAN}

Pertama, guru keagamaan di MTs Muslimat NU Palangka Raya menggunakan strategi pembelajaran daring dengan membuat video mengajar dan membuat group whatsapp untuk berbagi video, absensi dan tugas kepada siswa serta mengajukan pertanyaan tentang materi pelajaran yang belum jelas kepada siswa. Kedua, faktor pendukung strategi pembelajaran guru keagamaan pada masa pandemi covid-19 di MTs Muslimat NU Palangka Raya yaitu semua guru dan siswa memiliki Hp, ada internet di sekolah, dan semua guru maupun siswa memiliki aplikasi whatsapp. Ketiga, kendala yang dihadapi guru keagamaan dalam menjalankan strategi pembelajaran daring di MTs Muslimat NU Palangka Raya yaitu guru kesulitan memeriksa tugas siswa karena ada beberapa siswa mengirimkan tugas sekaligus tidak sesuai dengan jadwal pengumpulan tugas.

\section{REFERENSI}

Bhagaskara, A. E., Afifah, E. N., \& Putra, E. M, 2021, Pembelajaran Dalam Jaringan (Daring) Berbasis, ZAHRA: Research And Tought Elmentary School Of Islam Journal, Vol 2, hal 13-23.

Dewi, W. A. F, 2020, Dampak COVID-19 terhadap Implementasi Pembelajaran Daring di Sekolah Dasar, Edukatif : Jurnal Ilmu Pendidikan, Vol 2, hal 55-61.

Fauziyah, N, 2020, Dampak Covid-19 Terhadap Efektivitas Pembelajaran Daring Pendidikan Islam, Al-Mau'Izhoh, Vol 2, hal 1-11.

Hartati, N. S., Thahir, A., \& Fauzan, A, 2020, Manajemen Program Penguatan Pendidikan Karakter Melalui Pembelajaran Daring dan Luring di Masa Pandemi Covid 19-New Norma, Journal of Chemical Information and Modeling, Vol 53, hal158-167.

Hutami, M. S., \& Nugraheni, A. S, 2020, Metode Pembelajaran Melalui Whatsapp Group Sebagai Antisipasi Penyebaran Covid-19 pada PAUD di TK ABA Kleco Kotagede, Paudia: Jurnal Penelitian Dalam Bidang Pendidikan Anak Usia Dini, Vol 9, hal 126-130.

Menteri Pendidikan, 2020, Surat Edaran Nomor 4 Tahun 2020 Tentang Pelaksanaan Kebijakan Pendidikan dalam Masa Darurat Corona Virus Disease (COVID-19).

Majid, Abdul, 2013, Strategi Pembelajaran. Bandung: PT. Remaja Rosdakarya. 
Nata, Abuddin, 2014, Perspektif Islam Tentang Strategi Pembelajaran. Jakarta: Kencana Prenadamedia Group.

Nikmah, N, 2020, Strategi Pembelajaran Daring Pada Masa Pandemi Covid-19 (Studi Di Jurusan Akuntansi Politeknik Negeri Banjarmasin), jurnal idealetkik, Vol 2, hal 4551.

Pohan, Albert Efendi. 2020. Konsep Pembelajaran Daring Berbasis Pendekatan Ilmiah. Purwodadi: CV Sarnu Untung.

Puspitorini, F, 2020, Strategi Pembelajaran Di Perguruan Tinggi Pada Masa Pandemi Covid-19, Jurnal Kajian Ilmiah, Vol 1, hal 99-106.

Putria, H., Maula, L. H., \& Uswatun, D. A, 2020, Analisis Proses Pembelajaran dalam Jaringan (DARING) Masa Pandemi Covid- 19 Pada Guru Sekolah Dasar. Jurnal Basicedu, Vol 4, hal 861-870.

Rahayu, A. D., \& Haq, M. S, 2020, Sarana Dan Prasarana Dalam Mendukung Pembelajaran Daring Pada Masa Pandemi Covid-19, jurnal inspirasi manajemen pendidikan, Vol. 9, hal 186-199.

Rahayu, A. S., Amalia, A. R., \& Maula, L. H, 2020, Analisis Kesulitan Guru Dalam Pembelajaran Daring Di Masa Pandemi Covid-19 Di Sekolah Dasar, Jurnal PGSD, Vol 6, hal 1-6.

Rigianti, 2020, Kendala Pembelajaran Daring Guru Sekolah Dasar Di Kabupaten Banjarnegara, Elementary School, Vol 7, hal 297-302.

Rozi, Mochamad Fachrur, 2020, Antologi Penerapan Adaptasi Kebiasaan Baru pada Era Pandemi Virus Corona 19 di Berbagai Sektor Pendidikan. Tulung Agung:Akademia Pustaka.

Siahaan, M, 2020, Dampak Pandemi Covid-19 Terhadap Dunia Pendidikan, Jurnal Kajian Ilmiah, Vol1, hal 1-3.

Suhendro, E, 2020, Strategi Pembelajaran Pendidikan Anak Usia Dini di Masa Pandemi Covid-19,Jurnal Golden Age, Vol 5, hal 133-140.

Syafi'i, I., Sa'diyah, C., Wakhidah, E. W., \& Umah, F. M, 2020, Penerapan Video Pembelajaran Daring Anak Usia Dini Pada Masa Pandemi Covid-19, Al-Athfaal: Jurnal Ilmiah Pendidikan Anak Usia Dini, Vol 3, hal 140-160. 
Syarifudin, A. S, 2020, Impelementasi Pembelajaran Daring Untuk Meningkatkan Mutu Pendidikan Sebagai Dampak Diterapkannya Social Distancing, Jurnal Pendidikan Bahasa Dan Sastra Indonesia Metalingua, Vol 5, hal 31-34. 